\title{
Power Relations, Contestation and Identity Construction in Hausa Folklore from Niger Republic: A Case Study of Two Tales*
}

\author{
Chaibou Elhadji Oumarou \\ English Department, Université Abdou Moumouni de Niamey, Niamey, Niger \\ Email: chaiboueyahoo.fr
}

How to cite this paper: Oumarou, C. E. (2020). Power Relations, Contestation and Identity Construction in Hausa Folklore from Niger Republic: A Case Study of Two Tales. Advances in Literary Study, 8, 133-151. https://doi.org/10.4236/als.2020.83011

Received: June 1, 2020

Accepted: July 6, 2020

Published: July 9, 2020

Copyright $\odot 2020$ by author(s) and Scientific Research Publishing Inc. This work is licensed under the Creative Commons Attribution International License (CC BY 4.0).

http://creativecommons.org/licenses/by/4.0/

\section{(c) (i) Open Access}

\begin{abstract}
In this paper, I focus on the attitudes of Sarki (chief or king), Malamai (Islamic leaders or elite) and Azne (non-Muslim or pagan) as well as on their motivations for actions and on how they end up constructing identities in the process. For the sake of methodology, I will begin with summaries of the two tales to help readers not familiar with them; then I will follow the theme of power relations exploring the attitudes of the three characters through their interactions in the light of historical facts. The exploration will serve as a background for the contestation of the legitimacy of the political authority of the Sarki by Malamai and of Sarki's claim on the land by Azne. The background will also help better understand the ideological, social and cultural implications of the characters' actions, mostly the contestation which adds the identity dimension to their relations and sheds light on some of the social and cultural crises facing the Hausaland today. Then the process of identity creation will be the last section before the conclusion followed by a short biography of the storyteller. The tale Azne is the main primary source on which I will base my interpretative analysis, although some references will be made to some tales collected by (Stephens, 1981) that illustrate contests between a representative of the Malamai and one of the royal family on the one hand and another tale dealing with power relation and contestation that involves a Sarki and an Azne from Ciibaw's collection under study. The second tale is titled Babu sarki sai Allah (There is no king but Allah). The limitation to few primary sources will somehow make any conclusions provisional and it also suggests further research for a more comprehensive approach to the
\end{abstract}

*These tales have been taken from volume I of the collection of tales called Baakii Abim Maganaaa: Hiirat Albarka Ciibaw, an interview on several days conducted by Isaaka Dankuusu and Abuubakar Mahaman started on 15 April, 1971 at the Center for Linguistic and Historical Studies by Oral Tradition, an OAU/AU institution in Niamey. The three-volume collection was first published by the Centre in 1973, with a second edition in March 1979 from which this tale has been taken (Dakuu \& Abuubakar, 1973/1979). 
topic in particular and to the work of Albarka Ciibaw who is yet to receive adequate critical attention from scholars on Hausa oral literature.

\section{Keywords}

Hausa Folklore, Power Relations, Contestations, Identity Construction, Niger

\section{Summaries of the Two Tales}

Tale 1: $A Z N E$

The tale begins with an argument involving Sarki (the chief), Malamai (the Islamic religious clerks or leaders) and Azne (the non-Muslim or pagan). Sarki and Malamai claim legitimate right over the land and its people while Azne thinks they only have political power on the people but not on the land which he considers as his rightful legacy from his ancestors. Days after the discussion, Sarki sends his old mother into the village with a bull intended for anyone who is courageous and who has enough faith in Allah to accept to be buried alive with his mother when she dies. The old woman first meets the Malamai who hasten to grab the bull as they think it was some alms from her son to them. But when they learn about the conditions attached to the bull, they quickly tell the old woman to continue with her quest. No one dares accept to take the bull except Azne against the wishes of his family and friends who are convinced that he will be buried alive with the corpse of the mother of the chief. When Azne kills the bull, he secretly takes some entrails to Gaba (an eagle-like bird) into dagi (bush) and asks her for help on the day the old woman dies. Gaba accepts the offer and promises to help him. So, on the D-Day, Gaba stays very high in the sky, just above the cemetery to grant him anything he asks for from Allah. On that day, before the people place the dead mother's body on top of Azne in the tomb, he asks for permission to say his last wish. He is granted the permission after some debate. He then calls Allah (Gaba) and asks Him not to provide the land with rain for seven years to be repeated three times, which makes twenty-one years. Allah (Gaba) accepts. The panic-stricken assembly is divided between those who think they have to inform the chief and the others who think they should burry the woman in spite of Azne's threat. The first group wins and they send a delegation to inform the chief. Several delegations will have to come later to the cemetery to verify the previous information. Finally, the chief becomes impatient and decides to go and see for himself. Upon arrival to the cemetery, he angrily orders his mother to be buried. But his subjects refuse and demand that he accepts to hear the conversation between Azne and Allah. After the conversation, the chief orders Azne to come out of the tomb and let his mother be buried alone. Azne poses some conditions before coming out: that even after his death, the chief's children should not ask Azne's children to pay back the bull and that he (Azne) is the rightful owner of the land not sarki, the 
chief. The latter accepts Azne's conditions. The tale concludes with an explanation of the tradition by which Sarki, who is Muslim, provides a bull for the pagan ritual ceremony of budin dagi ${ }^{1}$ still being held every year at the village of Massalata in the local government of Konni, in Tahoua state.

\section{Tale 2: BABU SARKI SAY ALLAH}

This tale is about Azne and Sarki. Although a member of the chief's court, Azne refuses to greet Sarki in the usual "ranka ya dade". Instead, he says "babu Sarki say Allah" (There is no king but Allah). This attitude irritates the village chief who considers it as a disrespect of his personality and authority. To punish Azne, Sarki bribes Azne's wife with two bulls after he has given her husband a ring to keep safe for him. Then he asks Azne's wife to steal the ring and return it to him. Once he has the ring, Sarki throws it in a river where a fish swallows it. The same day Azne goes to the river and buys some fish, including the one that swallowed the ring. While preparing the fish, Azne discovers the ring which he left in a secret place in his home. He changes the hiding place and keeps everything to himself. Four years later, Sarki asks Azne to return his ring but Azne tells him that he has lost it. After threats from sarki, Azne presents the ring to him. Surprised, Sarki tells Azne and the court about what he did to trap Azne and the latter tells in turn how he got back the ring. Sarki becomes convinced that Azne is right: "there is no king but Allah" and offers apologies and compensatory gifts to Azne. It is also important to note here that the expression "babu Sarki say Allah" is a translation into Hausa of the Arabic "la-illahu-il-Allahu" which is a testimony of the uniqueness of Allah and one of the five pillars of Islam. Finally, the chief authorizes Azne to continue saying "there is no king but Allah" anywhere he wants.

\section{Introduction}

After examination of some Hausa tales (Furniss, 1996: p. 65) concludes that, in addition to the didactic and entertainment functions, tales can be an arena of contestation, a space in which human interactions reflect power relations; specifically, between talakawa "ordinary people" and sarakuna "the ruling class". "This space for the expression of anger", as (Rufa'i in Furniss, 1996: pp. 65-66) contends, "is perhaps what prevents the ordinary people from rising up in revolt that could damage both themselves and others. In my view, this space, this arena is rather like Speakers' Corner in London's Hyde Park where people can come

\footnotetext{
${ }^{1}$ Budin daji or "opening of the bush" is a yearly pre-jihad ritual ceremony that is still held, with the participation of local and sometimes national political authorities, to prepare the hunting season. It takes place in the fourth month of the (now) Muslim calendar when famous diviners (sarakin tsafi) are gathered to appease the gods of the ancestors for a good hunting season and to make predictions for the year to come. The usual place for the ceremony is the village of Massalata, in the local government of Konni in the region of Tahoua. Delegations come from Niger and Nigeria (mostly from Kano, Katsina, Zaria and Sokoto). The French anthropologist, H. Raulin (1962), who was a participant observer of the ceremony in 1961 and 1962, comments that although budin dagi is a pagan agrarian ritual, it is also to some extent an allegiance to the political power of the Sokoto Emirate. Raulin has given some explanation to this apparent contradiction to which I will come back later in the paper.
} 
and say whatever they like in their attacks upon those in power and then go back home to sleep in peace". Given the fact that Fulani have become the new rulers after the Jihad, Rufa'i's argument can be indicative of the type of joking relationships which, according to (Bichi, 1983/1985; Furniss, 1996) and Rufa'i quoted by (Furniss, 1996), exist between the Hausa and the Nomadic Fulani in general.

But (Furniss, 1996: p. 66) also cautions that Rufa'i's argument presenting tales as "safety valves in the maintenance of the status quo" needs more case studies of contexts in which political, religious, as well as social and cultural tensions are solved by involving the manifestation of symbolic representations such as the ones of the Sarki, the Malamai and the Azne in the current two tales under study. Similarly, the notion of tales as safety valves in helping the talakawa to vent their frustrations at the Nomadic Fulani in general and the rulers in particular, without fear of punishment, is reinforced by the joking relationships between the former and the latter. Such joking relationships offer indeed interesting perspectives from which we can look at Azne's apparently rebellious relations with Sarki and Malamai as representatives of the Fulani ruling dynasty in Sokoto. In fact, in addition to representing the ruling class, the Sarki as well as the Malamai represent the new triumphant religion of Islam which, following the Jihad of Usman Dan Fodio, has turned the Hausa land into a theocracy. This political change is reflected not only in tales but also in Hausa oral poetry. Thus, commenting on some praise songs about the ruling class in the post jihad Hausa land, (Bello, 1976: pp. 24-25) observes that

The leaders, especially the current ones and their immediate predecessors, came into power because of Jihad. As a consequence, since the Jihad (1804-1808) in Hausa land the enthronements of community leaders have depended on the Caliph in Sokoto. In other words, any newly enthroned leader is the representative of the Caliph and the leader of the Muslims of the area in question. This is why those rulers have been called Islamic rulers. (...) The Fulani community leaders who fought the Jihad took power from Hausa rulers in order to impose Islam².

It is clear from the above quote that there is no need for new rulers to come from traditionally well-established ruling families. This is because the most important criteria to become a ruler are to be a Muslim, to have belonged to the class of those who fought for the Jihad and to show allegiance to the Caliph of Sokoto and his ruling dynasty ${ }^{3}$. These criteria are the reason why the new rulers

\footnotetext{
${ }^{2}$ Sarakuna, musamman dai na yanzu da kuma na nan baya kadan ba da dadewa ba asalin shigansu gidan sarauta addini ne. Watau abin nufi a nan shi ne, kowa ya sani tun bayan kare jihadi wanda aka yi kan jaddada addini a karar Hausa daga 1804-1808, nadin sarauta ya koma hannun Sarkin Musulmi a Sakkwato. Watau duk wanda aka nada ya zama wakilin Sarkin Musulmi a kasar ikonsa, kuma shi ne shugaban addinin wurin. Don haka ne ma ake kiransu sarakunan addini. (...) Sarakunan Fulani sun yi jihadi sun karbi mulki daga hannun na Habe don su gyara addini ne... (pp. 24-25).

${ }^{3}$ Y. Urvoy qtd by Raulin (p. 256, note 1) reports, for example, that Konni at the time did not depend directly on Sokoto but on one of Usman Dan Fodio's sons called Sarkin Maky who was living in Binji, northwest of Sokoto.
} 
have been called "sarakunan addini" (Islamic rulers). But their failure to rule by Shari'a principles in accordance with the theocratic ideals quickly led to problems like corruption, nepotism, tribalism and racism as pointed out by (Nwabara, 1963); (Hiskett, 1989); (Mahaman, 2006); (Mahamane and Mahaman, 2006) and (Bunza, 2009) among others.

In fact, Bunza has made critical observations about the political changes that came after the Jihad. Many of the problems he pointed out are the same social ills that paved the way for the Jihad and its success in the Hausa land. As he reports,

The political situation started to change between the $18^{\text {th }}$ and $19^{\text {th }}$ centuries. The Jihad led by Sheikh Usman Danfodio changed the political organization in Hausa land. Since the victory of the Jihad leaders, they have become the new rulers and Islam the new dominant religion. First the rulers attempted to rule by Islamic principles, but soon they became lured into nepotism and injustice against the teachings of Islam. This led to hypocritical practices such as tribalism. It was at the peak of such nepotism, of pride in one's origins and social ranks, of deception and of tribalism that colonization started (2009: pp. 95-96) ${ }^{4}$.

This quotation provides a good background against which we can explore the possible tensions between the first two protagonists and Azne in our tale. These tensions are mostly cultural, political and religious. An indication of religious tension is inherent in the term Habe by which the Fulani in general call the Hausa people. In fact, according to (Nwabara 1963: p. 231) and (Baumgardt ${ }^{5}$, 2011: p. 232) the term Habe means pagan and as such he was the target of the Holy war or Jihad. Traces of religious tensions in the Jihad are found in some praise songs by singers like Narambada ${ }^{6}$ who sang for Sarkin Gobir Ahmadu Na Issa (Bunza, 2009). The titles of two of his songs are revealing: "Toya matsafa" (2009: p. 29) ["He who burns the pagan shrines"] and "Mai shirin fada da arna" (2009: p. 29) ["He who is getting ready to fight the pagans"]. In the second song, the singer praises the previous rulers who fought the pagans before Sarkin Gobir Ahmadu in order to encourage him to fight them as his predecessors did.

Storytellers are also important witnesses of these changes and their narratives

\footnotetext{
4"Daga karni na goma sha takwas zuwa karni na goma sha tara abubuwa suka fara sauyawa. Yunkurin jaddada addinin musulunci da mujaddadi Shehu Usman Danfodio ya jagoranta ya sauya tsarin siyasar Hausa. Da aka ci nasarar jihadi musulunci ya ci kasar Hausa sarauta ta koma hannun wadanda suka jagoranci jihadi. Da farko abin ya so ya bi tsari irin na Musulunci da baya abin ya sauya son zuciya ya shiga ciki aka bi tsarin gadon-na-gaje-ka ba tare da bin cancanta ta shari'a ba. Wannan shi ya rayar da wani sabon munafunci a zukatan wasu masu mulki da kabilun da suka fito daga ciki na kabilanci ba tare da kula da musulunci ba. (...) Ana cikin wannan hali na bugun gaba da asali da gado da yaudara da kabilanci Bature ya bayyana" (pp. 95-96).

${ }^{5}$ Baumgardt is specialist of Fulani oral literature from Adamaawa, a region of northern Cameroun that was part of the Sokoto Caliphate (p. 231; notes 4 and 5).

${ }^{6}$ Aliyu Muhammadu Bunza wrote a trail blazing critical work on this famous praise singer. The book is titled: Narambada. Lagos: Ibrash Islamic Publications Centre Ltd., 2009. To my knowledge, this is the most complete critical work in Hausa language devoted to this well-known singer, apart from B.A, MA theses and Ph.D. dissertations.
} 
are the result of a mediation between historical events and their imagination, between reality and fantasy. In the same line of thought, (Yahaya; 1972: p. 37) has aptly observed that "Stories are fantasies shaped out of realities". Franz Boas quoted by (Bichi, 1979: p. 100) also notes that "In the tales of a people, those incidents of everyday life that are of importance to them will appear either incidentally or as the basis of a plot. Most of the references to the mode of life of the people will be an accurate reflection of their habits".

In our tale, these incidents are in fact the basis of the plot of the story through the mediation of the three major stock characters of Sarki, Malami (pl. Malamai) and Azne. Of course, there are other characters, mostly the Talakawa or ordinary people. But by introducing the three characters in a debate at the very beginning of the tale, the storyteller foregrounds their importance in the narrative. So as the story unfolds, we learn more about each of them in their relations one to the other, especially between Sarki and Azne, both contesting each other's legitimate influence and legal right on the land (kasa). In fact, Azne claims legitimate tenure on the land as a legacy from his ancestors while Sarki has only political and religious (Islamic) power on the people of the land. But the latter claims political control (iko) on the land as well as on the people. On their part, the Malamai equally claim political power on the people and the land. Moreover, Azne's opposition to such claims adds an identity dimension to the contest as he represents local beliefs and Talakawa (ordinary people) while Sarki and Malamai represent the new theocratic sarauta (political power) and elite respectively. All this has created a complex network of relationships colored by manifestation of power by some and its contestation by others for diverse reasons.

In this paper, I focus on the attitudes of the three major characters, on their motivations for actions and on how they end up constructing identities in the process. For the sake of methodology, I will begin with the theme of power relations by exploring the attitudes of these characters through their interactions in the light of historical facts. The exploration will serve as a background for the contestation of the legitimacy of the political authority of the Sarki by Malamai and of Sarki's claim on the land by Azne. The background will also help better understand the ideological, social and cultural implications of the characters' actions, mostly the contestation which adds the identity dimension to their relations and sheds light on some social and cultural crises facing the Hausaland today. The process of identity creation will be the last section before the conclusion followed by a short biography of the storyteller. The tale Azne, about seven (7) pages long, is the main primary source on which I will base my interpretative analysis, although some references will be made to another tale dealing with power relation and contestation that also involves a sarki and an azne from the same collection by the same author. The tale is titled Babu sarki sai Allah (There is no king but Allah). The limitation to a few sources will somehow make any conclusions provisional and it also suggests further research for a more comprehensive approach to the topic in particular and to the work of Albarka Cii- 
baw who is yet to receive adequate critical attention from scholars on Hausa oral literature.

\section{Power Relations and Contestation: The Interactions among Sarki, Malamai and Azne}

\subsection{Sarki and Malamai}

While the title of the tale foregrounds Azne as the would-be hero of the tale, the debate with which the tale has begun is a good indication of the importance of the relationship involving Azne, Sarki and Malamai in the story. Sarki represents political and religious authority while Malamai stands for intellectual and religious elite. As shown in the quote from (Bello, 1976) above, Sarki and Malamai represent respectively the post Jihad rulers and elite of the new theocracy in the Hausa land. In other words, they stand for royalty and aristocracy respectively. In fact, Sarki and Malamai are representatives, at different levels, of the Caliph of Sokoto whose influence on the land that is known today as Republic of Niger has been historically established. For example, (Maikorema, 2006: p. 152) explains that the Sudan, which includes Niger Republic, witnessed the emergence of a big political entity, the Sokoto Caliphate, composed of about thirty emirates with large autonomy even if, it is true, to some extent the Caliphate in Sokoto had an influence on each of the emirates mostly through the issues of enthronement, of the payment of yearly or bi-yearly tributes, of the implementation of Shari'a and of mutual assistance in war situation.

On the social level, in line with the Jihad which was a trans-ethnic movement, the social division was operated on a purely ideological basis: Muslims on one side and non-Muslims on the other side, paving the way for a community of believers. Moreover, the Jihad also led to the creation of a new ruling class essentially composed of religious persons whose political legitimacy depended on their Islamic piety and knowledge (emphasis added).

The above quotation brings a good historical illustration of and a significant commentary on the social, cultural and ideological context that serves as background to the story of our tale. Moreover, it helps us to better understand the tensions that characterize the relationships among the village chief (Sarki) and Azne on one hand and between the chief and Malamai on the other hand. As a matter of fact, the tale opens with a debate on the legitimacy of each of these characters concerning the land and the people of the village. While Azne concedes that Sarki and Malamai have political control on the people, the last two characters claim political as well as religious legitimacy on the land and on the people.

In the quote below from the tale, the storyteller shows Azne and Sarki in a direct dialogue that illustrates a verbal confrontation: Azne contests Sarki's claim on the land, posing himself as its unique and legitimate inheritor. The storyteller also comments that Sarki does not agree with Malamai concerning their claim of political authority on the people and the land: 
It is an argument over land issue involving Azne, Sarki and Malamai. Azne claims to be the unique legitimate owner of the land, Malami (sing. of Malamai) and Sarki also claim ownership of the land. Azne said: "Sarki, the people are under your political authority; but the land is my property: it is a legacy from my father".

Sarki replied: "even if it is a legacy from your father, the authority can take it from you: in fact, I seize it from you".

Azne said: "No. You can't mix your things with mine. It is better you keep on your political leadership role. Because I am the only rightful owner of the land. You have political authority on the people. Every person in the land is under your political authority. But this land, on which we are, belongs to me by native right: this land is mine as a legacy from my father"

Malamai also claims that the land and the people belong to them. But Azne and Sarki do not agree with them (p. 29) ${ }^{8}$.

The last comment by the narrator indicates another contest between Sarki and Malamai over the land and its people. In fact, (Bello, 1976) in the quote above has already pointed out that any post-Jihad ruler is a representative of the Sokoto Caliph in the land under his political administration. From this perspective, the Malamai are in competition with Sarki when they claim equal rights with him concerning the administration of both the land and its people. Historically the competition can be related to the Jihad which, according to Maikorema in the quote above, has brought a new ruling class composed of intellectual and religious elite whose authority and legitimacy are rooted in their piety and religious knowledge. So as members of the new ruling theocracy (Nwabara, 1963: p. $237)^{9}$, the Malamai and Sarki owe allegiance to the same Sokoto Caliphate and its ruling dynasty. As a consequence, Sarki and Malamai have to work together to implement the Shari a, for example. But their claims for the same rights as Sarki is indicative of conflicts of interests because they consider themselves as representatives of both the royalty and aristocracy in their position as religious elite.

\footnotetext{
${ }^{7}$ Historians Mahamane and Mahaman have reported two categories of Azna in the Adar region which includes Tahoua state: "The oldest group settled in Adar is that of Azna: among them we distinguish Aznan ramu or Azna of the caverns whose collective memory has lost the traces of migrations and who consider themselves as "Yan kasa" (indigenous) compared to Azna Mahalba who came after. It is these Aznan ramu who will keep, even after the advent of centralized political powers [i.e., Caliphate], the traditional power linked to earth worship. The Azna Mahalba, on the other hand, who have known more advanced organizations, contributed to the founding of the village communities" (p. 50).

${ }^{8}$ Gardamak kasa ce da anka yi da azne, da sarkin gari da malamai. Azne ya ce shi adda kasa, malami ya ce shi adda kasa, sarki ya ce shi adda kasa. Azne ya ce: sarki, mutane ag gareka, ni kasa tawa ce, ga ubana na gade ta.

Sarki ya ce: ko ka gade ta ga ubanka, iko babu abun da bay yi ba, na amshe duk

Azne ya ce: a'a, ba ka gama naka da nau. Kay de koma busa ga kay ka ikona. Amma hwa ni ka ikon kasa, kay ko kay ka ikon mutane. Duk inda mutun ya kwan ya tashi naka ne. Amma hwa kasa wagga da mu ke takawa, ni ka ikon ta, tau ce, ga ubana na gade ta..

Malamai sunka ce su ko da kasa da mutane, su na so duk na su ne. Azne ya ce bay yarda ba. Sarki ma ya ce bay yarda ba (p. 29).

${ }^{9}$ According to (Nwabara, 1963), each Emirate was administered by a member of the Fulani dynasty as Emir assisted by a Wazir as Chief Adviser, an Alkali as Judge and Chief of Police and an Imam. All of these are members of the Islamic elite mentioned by Maikorema.
} 
Such conflicts are illustrated by tales collected in Niger Republic by Connie L. Stephens (1981: pp. 511-18) for her Ph.D. dissertation. Based on this Ph.D. research, she carried out further research on selected tales (Stephens qtd in Coles and (Stephens, 1991: pp. 221-231) involving competitions between a Malam's daughter and her husband, a prince, who has her as a second wife. Soon after their marriage, the prince-husband challenges his second wife by asking her to make him meal out of stones while giving rice to his first wife to do the same. The second wife consults her father who uses his religious powers to transform his daughter's stones into rice and the first wife's rice into stones, thus allowing his daughter to win the contest against her royal husband. Then in another contest, the prince decides to travel to a far country. But before leaving he orders his second wife that her mare bear his stallion's colt while she herself bears his own son before his return. As soon as she informs her father, he uses his religious powers again to send her after her husband who she easily seduces, as a whore, into sharing his bed on condition that he accepts their horses to copulate. So, by the time he returns home, the Malam's daughter is pregnant by him and her mare by his stallion. Once again, the Malam's daughter wins against her royal husband. The wife's victories represent the superiority of the Malam's family over the royal one, which is a good illustration of the tensions between the two classes of the new Islamic theocracy.

From the tale collection under study, there is another illustration of a religious or ideological conflict between Sarki and Malamai when the former's mother comes near the latter with her bull. The Malamai hasten to take possession of the bull, thinking it was some alms from the Sarki to them. Their reaction is not only illustrative of their expectations but also of their dependency towards the chief, as representative of the Emir, while it equally suggests that they live mostly by alms. But the most important ideological aspect of their attitude is their refusal to take the bull on Sarki's conditions, which implies a form of pagan practice through which rulers' parents are buried with people alive. In a dialogue between Azne and gaba, the latter alludes to these cultural practices when she reminds Azne that "sarkis mother cannot be buried alone...." (Azne p. 32; emphasis added $)^{10}$. In other words, the condition that Sarki attaches to the bull illustrates a form of religious syncretism which some of the post-Jihad Malamai might not be willing to accept. In this sense (Mahaman, 2006: p. 122) reports a categorization of the Malamai or religious elite as Ulama al-sul (the elite very close to the ruling class) and the Ulama ad-din or Ahl-al-Zikr who are very close to the people and who do not care much about the radical and purist ideology of the Jihad (note 4; Nwabara, 1963: p. 238). Therefore, the first category of Ulama al-sul may be the ones in our tale as they seem to refuse to side with Azne who represents the common people.

Other situations of conflict of interests at the level of the ruling dynasty are well described by (Bunza, 2009) as quoted above. The critic shows how nepotism, the pursuit of personal interests and corruption have characterized the post

\footnotetext{
10"Ita uwagga taashi baa a iya binnee ta ita daya ba...".
} 
Jihad period. But the worst aspect that dominates in this period is the feeling of tribalism and injustice even among the ruling class mainly because the old traditional social structures have been replaced by new ones with a mosaic of actors from different social, cultural and religious backgrounds. On top of all these problems, there are the facts that old ruling families have been put out of competition apparently for religious reasons and the failure of the new rulers to govern by the principles of the Shari'a as promised during the Jihad. As Bunza reports,

The Jihad led by Sheikh Usman Danfodio changed the political organization in Hausa land. Since the victory of the Jihad leaders, they have become the new rulers and Islam the new dominant religion. First the rulers attempted to rule by Islamic principles, but soon they became lured into nepotism and injustice against the teachings of Islam. This led to hypocritical practices such as tribalism. It was at the peak of such nepotism, of pride in one's origins and social ranks, of deception and of tribalism that colonization started (2009: pp. 95-96) ${ }^{11}$.

This quotation indicates that the new rulers may not come from local ruling families but from different ethnic groups since the most important criterion for becoming a ruler is the religion of Islam. The possibility of having a ruler who is not from the community over which he is ruling is reinforced and illustrated by the argument between Sarki and Azne who considers himself as the inheritor of the land by native law.

\subsection{Sarki and Azne}

I took with me pagans of many tribes, with trumpeting and drumming in the gathering at Kano (Aliyu, Emir of Zaria qtd in Skinner, 1977: p. 53).

Some preliminary questions that quickly come to mind are why does Sarki send his old mother with a bull and conditions attached to it, especially not very long after his argument with Azne over the right to the land and to the people? Is Sarki's request through the bull in accordance with the principles of the Sharia? What are the cultural implications of Sarki's request, of the Malamai's refusal and of Azne's acceptance of the bull? In the following analysis, I intend to provide some answers to these questions.

As suggested earlier, Sarki's request may have originated from a pre-jihad cultural practice and that he may belong to the generations of migrants living in Hausa land, especially in the region of Tahoua. In fact, (Oumarou, 2018: p. 4) quoted Mahamane and Mahaman, two historians from Niger Republic, who de-

\footnotetext{
${ }^{11}$ Yunkurin jaddada addinin musulunci da mujaddadi Shehu Usman Danfodio ya jagoranta ya sauya tsarin siyasar Hausa. Da aka ci nasarar jihadi musulunci ya ci kasar Hausa sarauta ta koma hannun wadanda suka jagoranci jihadi. Da farko abin ya so ya bi tsari irin na Musulunci da baya abin ya sauya son zuciya ya shiga ciki aka bi tsarin gadon-na-gaje-ka ba tare da bin cancanta ta shari'a ba. Wannan shi ya rayar da wani sabon munafunci a zukatan wasu masu mulki da kabilun da suka fito daga ciki na kabilanci ba tare da kula da musulunci ba. (...) Ana cikin wannan hali na bugun gaba da asali da gado da yaudara da kabilanci Bature ya bayyana (pp. 95-96).
} 
scribe the Hausawa from Niger as not forming "a homogenous group that originated from a precise place. Many groups [of migrants] came from diverse horizons and they succeeded in integrating themselves in the migration tradition of the Hausa people. Others were not certainly from Hausa origin, but they have been assimilated by glottophagia [the loss of their mother tongues in favor of the Hausa language] while keeping their own migration tradition alive".

Sarki and Azne may therefore belong to different ethnic groups, but they both seem to continue practicing a form of cultural and religious syncretism by which they mix pre-jihad with Islamic traditions. Syncretism is indeed a characteristic of the period before and after the jihad (Mahamane, 2013; Bunza, 2009; Hamani, 2006 ${ }^{12}$; Besmer, 1973; Raulin, 1962). This characteristic can help to explain why Azne grants Sarki only political authority on the local population and deny him any claims on the land. As anthropologist Raulin has pointed out, the search for peace and the difficulties to rule over a vast Caliphate forced the Sokoto ruling dynasty to grant some cultural autonomy to some populations in Niger Republic in order to secure their collaboration. Raulin's argument is supported by (Nwabara, 1963) ${ }^{13}$ and (Mahaman, 2006: p. 135). The latter points out that “... even before the death of the Shehu, the new jihad-based administration had difficulties in being respected by the citizens of the Hausa land, who were accustomed for centuries to a Hausa system of administration. To solve this problem, Muhammad Bello would have asked the Shehu for permission to use the titles used in the Hausa administration, which the Shehu agreed to" (emphasis added). Thus, the Jihad leaders "sought collaboration with the Hausa people, whether Muslim or animist. This fact is so well established that the warlords of Usman Dan Fodio (...) recognized to the natives the control of the land, not only in the legal sense, but with regard to all the religious traditions related to the soip' (Raulin, 1962: p. 254; emphasis added). As a consequence, Raulin reports two types of Islamization in Niger Republic.

The first type concerns the predominantly Zarmaphone region of western

${ }^{12}$ (Hamani, 2006) claims that in most of the Hausa lands the sarki or ruler was elected by electoral colleges such as the Taran-Gobir (the Nine of Gobir); the Tara-Ta-Kano (the Nine of Kano) and the Sarakunan Karaga (the six members of the electoral college) in Katsina. Hamani adds that the political organization in those Hausa lands was [and may still be] characterized by "The presence of pagan religious leaders among the voters, even after the Islamization of rulers. Durbi, in Katsina; Sarkin Anna in Gobir, the pagan religious leaders of Kwanni" (176; emphasis added). In addition, each newly elected sarki has to undergo a ceremony with pre-Islamic origin known as Wakan Sarauta (enthronement ceremony) which, according to Hamani, "symbolized the marriage of the prince with the land. (...) In Katsina his [the prince's] alliance with the soil was symbolized by an ear of millet, an ear of sorghum, of maize and beans that he had to hold in his hands at a certain moment" (ibid.). Still more interesting is the case of Kwanni in Tahoua State "where an electoral college exclusively composed of pagan religious leaders was to propose to the (Muslim) dignitaries the name of the souvereign" who would be elected (ibid.).

${ }^{13}$ (Nwabara, p. 238) contends that after the death of Bello in 1837 the empire faced a new and difficult period when the religious fervor declined as the result of political leaders much more interested in worldly matters: "It was an anticlimax of all that Usman had stood for, and critics were many who saw in the period a means whereby his reforms were described as a complete failure. Indeed, anarchy had set in in many of the Emirates, reminding one of the pre-Fulani period, and revolt against the authority of Sokoto was constantly being led by Hedeija in 1851". 
Niger, mostly along the Niger River valley that covers the regions of Say and Birni N'Gaouré in particular. According to (Raulin, 1962: p. 252), in these regions, Islam was introduced by the Torobé and Bitinkobe ethnic groups. He argues that "Their action, now brutal, now skillfully conciliatory, was intended as much to get land as to impose their power. (...) Land occupation, religious and political facts are intricately linked that there is no question of dissociating them". But Raulin adds that in Gourmantché and Téra regions, "Islamic rituals and pagan practices are closely related. Each of the two religions has its own sphere of action; the first is linked to people, the second to Mother Earth..." (1962: p. 252; emphasis added). The anthropological facts from the quotes above shed some light that can help us to better understand the dispute between Sarki and Azne. It is indeed clear from the quotes that land, or Mother Earth, is the domain of Azne who, as his name indicates, is linked to the soil as a native. Azne's attachment to the soil is an indication of his status as a Talaka or common person and of his traditional beliefs which make him a rightful claimant against his Sarki. As for the latter, the quote suggests that his legal authority is limited to the political and religious administration of the people.

The second type of Islamization relates to Eastern Niger, covering most of the Hausaphone land. "Contrary to the land and religious conquest led by the Fulani in the Niger River valley, the holy war (Jihad) in Hausa land was more concerned with politics and religion than with territorial conquest. The Fulani leaders sought less the creation of a coherent state than the imposition of their will on the sedentary farmers of the lands on which they led their cattle to pasture" (1962: p. 253). This quote also suggests that post-jihad rulers have mostly political and religious power on the local populations while the lands remain the property of the indigenous peoples with whom the rulers can negotiate pasturage for their livestock. It follows from the two quotes above that the two types of Islamization in Niger have left the local land issues under the control of the indigenous populations. From this perspective, one can infer that Sarki in our tale has abused of his power by confiscating Azne's land. There is also abuse of power by the Malamai through their claim on the land. Similar tales that expose the abuses of power and injustice by rulers in Hausa land have been documented by scholars like (Bunza, 2009), (Mahaman, 2006), (Furniss, 1996) and (Yahaya, 1972). In the next section, I intend to explore the impacts of the interactions among Azne, Sarki and Malamai and how they expose their identities in the process. In other words, I will investigate how the storyteller Albarka Ciibaw constructs a Hausa identity in his tale Azne.

\section{Identity Construction: Symbolic Representation of Talakawa and Sarakuna by Azne, Sarki and Malamai}

Hausa folklore is a deep well from which we can draw ample data for our insights into the cultural conceptions and behavioural attitudes of the Hausa people (Kirk-Greene in Ahmad, 2018: p. 1). 
Commenting on Frank Edgar's collection of Hausa Tales and Traditions, (Skinner, 1980), who translated the collection from Hausa into English, notes that the prime character of Edgar's story-tellers is the non-Muslim Hausa known as Azne or Bamaguje. He figures in many tales of contest between him and Malam (singular for Malamai). Skinner sees the contest as symbolic of the historical conflict of Jihad. It is important to recall that Major Frank Edgar was a British colonial administrator in Northern Nigeria from 1905 to 1927 (Aminu, 2014: p. 18). In other words, Skinner's observation is based on Hausa tales mostly from Northern Nigeria; but the observation is also useful for the context of Niger Republic, especially for the tale under examination. In fact, it opposes azne to Malamai on the one hand, and Azne to Sarki on the other hand. Because the latter and Malamai are under the influence of the Caliph of Sokoto, they represent Islamic ideology and identity while Azne symbolically represents a mixture of local beliefs and Islam which may be the most important reason of his indirect conflict with Malamai. By indirect conflict, I mean a lack of direct verbal confrontation as there is no direct dialogue between Azne and Malamai. But why isn't there any direct dialogue between Azne and Malamai? Is the absence of direct dialogue synonymous of indifference or of religious intolerance?

Recognizing the importance of conflicts or contests achieved through dialogues in Hausa tales, (Furniss, 1996) argues that the conflicts are usually acted out by way of encounters and interactions between characters. Furniss recalls the classic dual representation of human characters in Hausa tales as a way storytellers contrast partners in joking relationships such as the city slicker against the country bumpkin; the non-Muslim Hausa, the Bamaguje (or Arne), against the Islamic teacher, the Malam; the Kano man against the Katsina man, etc. According to Westley quoted by (Furniss, 1996: p. 58), such dualities represent the embodiment of ideas and identities. What is more, the interactions of opposed characters represent the storyteller's working-out of ideas that contain within them internal contradictions as illustrated by Azne, Sarki and to some extent the Malamai.

We know already that Azne shows some signs of conversion to Islam through his speech. For examples, when Sarki's policemen come to arrest him at home, they announce their arrival in the usual Muslim greetings: "salaamu aleekum may gida" (peace be upon you, household leader). Azne replies: "ammin aleekus salaamu" (peace be upon you, guests). It is also important to recall that Azne does not deny Sarki's or Malamai's politico-religious claims on the people of the village. He rather claims native rights to the land, which is illustrative of the historical agreement by which the Jihad warlords "recognized to the natives the control of the land, not only in the legal sense, but with regard to all the religious traditions related to the soip' (Raulin, 1962: p. 254; emphasis added). It is very interesting to note that Sheikh Usman Danfodio himself might have given some support to this agreement probably in the hope that with time Islam would definitely become the dominant religion. As a matter of fact, (Raulin, 1962: p. 155) 
reports that some Azna priests he met during the budin daji ritual ceremony informed him that the Sheikh "would have put to the contest the title of Serki $n$ 'Safi (in the sense of chief of the diviners). It is an ancestor of Dan Deguel of Massalata [village] who would have prevailed being the only one to guess what was hidden under a calabash: a rabbit' (note 3; emphasis added). Raulin cautions however that the story may be a myth created by the Azna priests to justify the recognition of their power by the Jihad warlords. For my part, I think it may also be a way for the Sheikh to effectively test the priests' divination capacity in making accurate predictions. In any case, these syncretic traditions are reflected in the character of Azne whose name symbolizes his attachment to the land and to the local cultural traditions. In this sense, Azne is equivalent to the Fulani term Habe, which means pagan.

Further illustrations of Azne's symbolic representation of the pagan identity are shown during the melodramatic scenes at the cemetery where he is taken to be buried alive with the corpse of Sarki's mother. First, he asks permission to reenact and represent something he calls his "tradition": "Inaa son nii koo ku bar ni in yi taw al aada" ["I would like your permission to practice my tradition"] (p. 35; emphasis added). But it is interesting to know that that tradition refers to the agreement between Azne and gaba, the bird who is going to play the role of Allah. So, when he calls Allah, gaba answers with the confirmation of his wishes that after he is buried with Sarki's mother Allah will not rain for twenty-one years. When the gullible crowd gathered for the burial of Sarki's mother hears the positive reply from Allah, they are all dumb stricken because they did not expect Allah to answer positively to the wishes of someone like Azne who believes more in his traditional religion than in Islam. The following expressions are illustrative of the reactions from the crowd to Azne's dialogue with Allah:

“dada gaa Azne Allaa yaa baa shi. Azne yaa kiraayi Allaa, Allaa yaa amsaa mishi" (p. 35).

"Wow, Azne has become Allah's elect. Azne called Allah and Allah answered him".

"kay wani rikicii mutanenku Allaa gaa wani shammaataa. Azne yaa kay haka, hadda magana da Allaa..." (p. 37).

"Hei! there is a problem, here is deceptiveness. Azne has reached the point where he can talk with Allah" !

These expressions translate the people's surprise and doubt at Azne's revealed position as someone special who has been able to talk to Allah and receive what he has asked Him for.

At first the crowd is divided on what to do because they do not want to inform Sarki for fear of brutal punishment and they do not want to refuse Azne's request and face the terrible consequences. The narrator summarizes their dilemma as follows: "Bizneewaa lahanii kuma hwadawwaa [sarki] lahanii" ["to bury Sarki's mother is a crime and to inform Sarki about the situation is also a crime"] (p. 35). But they end up deciding against Sarki's order to bury his moth- 
er because they argue that he is not Allah: "sarki baa Allaa nee ba $a^{14}$ ["Sarki is not Allah"] (p. 36). This announces Azne's victory even before Sarki is informed about the new situation. As a matter of fact, when Sarki hears the conversation between Azne and Allah he orders him to get out of the tomb and let his mother be buried alone. But Azne refuses first and when Sarki insists he poses his conditions: "Azne said: no, I do not agree, I agree on one condition: you have political control over the people and I have the right on the land. Sarki replied: "get out of the tomb, I give you back the land, I keep political control over the people" (p. 39; emphasis added $)^{15}$.

It is important to recall that sarki gave the bull to his mother to look for someone who is courageous and who has enough faith in Allah to accept to be buried alive with his mother when she dies. This is clearly a test for bravery and faith in Allah ${ }^{16}$. In this sense the malamai's refusal can be considered as their critique of the pagan aspect illustrated by the burial of people alive with Sarki's dead mother and at the same time as indicative of their desire to keep Islam clean of any pagan tradition. As a result, their action marks their difference from both Sarki and Azne. But the latter's acceptance of the bull not only likens him to Sarki through the pagan practice of burying people alive with dead bodies but also shows his courage starting with his attitude to sarki's mother while accepting the bull: "too kaawoo saa in kiz zoo yaw kak ki ini, mutu" ["Alright. Give me the bull and I don't care if you stay alive for the rest of the day: die"] (p. 31). Similarly, later in a discussion with his family members Azne explains that he has accepted the bull "by bracing up his courage, out of pungent courage, because this bull has been shown to malamai and they fail to take it' (ibid.; emphasis added $)^{17}$. When his family members insist that he should return the bull, Azne asks them: "if I return this bull will my action be considered courageous? They ${ }^{14}$ In the tale "Babu Sarki Sai Allah", another Azne character challenges the authority of the sarki or village chief by refusing to greet him in the proper traditional way like "ranka ya dade" or "Allah ya baka nasara." Instead, the Azne enters the chief's court, of which he is a member simply saying "babu sarki sai Allah" (there is no king but Allah). This attitude irritates the village chief who sees it as a disrespect of his authority to the point that he seeks the complicity of Azne's wife in order to trap Azne and have some reasons to physically eliminate him. In that sense, sarki gives his ring to Azne for safe keeping until the day he asks Azne for it. Afterward sarki bribes azne's wife with two bulls and she returns the ring hidden by her husband to sarki. The latter throws it in a river where a fish swallows it. By coincidence, the same day Azne goes to the river and buys the same fish that swallowed the ring. While preparing the fish himself, Azne discovers the ring which he later hides in new secret place. Four years later, sarki asks for his ring. At first azne tells him that he has lost the ring; but when sarki threaten to cut off his head Azne brings back the ring. Surprised, sarki tells him how he got the ring from his wife and threw it in the river. Then Azne tells sarki how he got back the ring with Allah's help, which convinces sarki that Azne is right; babu sarki sai Allah. As a result; sarki offers apologies to Azne with many gifts to right the wrongs he did to him and gives him the permission to continue greeting him as he has always done by saying "babu sarki sai Allah." Once again, Azne has won against sarki.

15“Aznee ya cee: aa'aa, nii ban yarda, yardaataa daya cee, kay ad da mutaanee nii ad da kasaa. Sarkii ya cee may: hutoo naa ba ka kasa, nii da mutaanee" (p. 39; emphasis added).

${ }^{16}$ Note that in the tale Babu sarki say Allah, it is rather azne who tests sarki's faith in Allah, a test that sarki fails. These tests of faith in Allah are perhaps indicative of some doubt concerning the nature of the characters' true faith in Islam.

17“ busa karhin zucciyaataa na amsoo shi, busa yaajin uwaz zuciya, dan sabooda san nan, an kay shı ga maalumay sun cee baa su amsaa tay" (ibid.). 
said: if you return this bull, that will be considered as a courageous action. He replied: no, I will not be courageous by returning this bull" (ibid?) ${ }^{18}$.

So, through the acceptance of the bull Azne exhibits his bravery by taking up the test of Sarki. He also proves that he is more courageous than the Malamai who fail to take up Sarki's challenge. All this is indicative of the tensions that characterize the relationships among these characters and features their different identities in the process. The most evident expressions of these identities are sarauta symbolized by Sarki, religious elite symbolized by Malamai and Talaka and traditional beliefs symbolized by Azne. But what is very interesting about this tale is Azne's victory against both Sarki and Malamai. The victory shows them as fools who have not been able to discover his deception. In his attempt to categorize the Hausa tales in Hausa Tales and Traditions, Skinner finds out that "nine out of ten times it is Arne that prevails and the learned Malam shown to be the fool" (1980: p. 34). Our tale belongs to this category because Azne's victory against Sarki, who represents religious and political power, and against Malamai, who are the religious elite, makes them all look like fools. In addition, Azne also wins the support of the Talakawa during his struggle with Sarki. In fact, after the surprise at Azne's power to talk with Allah, the crowd decides to go and inform Sarki: "Let us go and tell Sarki because Allaa has accepted his wishes. He who has Allaa's mercy must be obeyed" ["mu hwadoo ma sarkii tunda Allaa yaa baa shi [azne]. Wanda Allaa ya baa, ay biyaa tay a kee doole"] (p. 37). Of course, the Talakawa are also made to look like fools by Azne's deceptive redemption, but if he can deceive Sarki and the Malamai who consider themselves as the elite, why not the Talakawa who are considered as ignorant or illiterate?

Azne's attitude towards sarki and malamai is illustrative of Rufa'i's insightful interpretation of the way the Hausa lower class views the predominantly Fulani upper class and the Nomadic ones as the result of the historical Jihad that has transformed the social and political organization in Hausa land. According to (Rufa'i, qtd in Furniss, 1996: p. 65), living side by side has created familiarity and joking relationship between the Fulani and the Hausa people in general. If this is not the case, Rufa'i concludes, "then it must be that Hausa people are venting their frustration at the fact that the Fulani have come to rule over them. Their frustration appears in tales where they can say what they like to indicate to the Fulani that it is not intrinsic cleverness that has brought them to power. Put another way, how could it be that wandering nomads have the wit to hold down city people? ..."

The victory of Azne over Sarki and Malamai as representatives of the ruling class is perhaps an artistic answer to Rufa'i's questions. Moreover, the victory is an illustration that tales often show "the victory of the weak over the strong; not through an open confrontation, but because the weak resorts to wittiness" (Baumgardt, 2011: p. 238). The incidents that have made up the plot of the tale are also indicative of the creativity of the storyteller in his capacity to shape and

18“ in na mayda sanga naa yi mazaakuuta? Sunka cee: in ka mayda sanga ka yi mazaakuuta. Ya cee. aa' aa, bun yi mazaakuuta ba in na meeda saa" (ibid). 
reshape local people's identities. For those who seek to understand some of the current social conflicts facing the Hausa heartlands in Niger, the tale also reveals some of the early episodes of the conflicts. As such the tale illustrates the resilience and dynamism of folklore in its capacity to integrate old and new situations and concerns in order to put them into newer perspectives.

\section{Conclusion}

This paper has shown how storytellers like Albarka Ciibaw are able to cast critical looks at their societies' social, political and cultural organization through the depiction of the relationships among characters. It has turned out that the relationships presented in our tale have historical origin in the post Jihad Hausa society which has witnessed important changes on the political, social and cultural levels. One of the most important characteristics of this society is the joking relationship between the (Nomadic) Fulani and the Hausa peasants. Storytellers have used this joking relationship to create spaces for the expression of anger and frustration by characters confronted to various forms of injustices perpetrated by the new theocratic rulers. In Azne, our tale, the expression of anger and frustration has led to Azne's contestation of the authority of the chief and of the religious elite, represented by the Malamai, on the matter of land. Therefore, through the attitudes of these characters, the tale has become an arena of the expression of power by Sarki and Malamai and a space for contestations against the ruling class by characters like Azne. The victory of the latter on the former has been the storyteller's artistic response to Rufa'i's interrogation about the Nomadic Fulani who have had the wit to hold down Hausa city dwellers. But beyond this humorous and artistic answer by the artist Albarka Ciibaw, the tale has also opened some windows of opportunity for those trying to understand some of the salient social and cultural crises facing the Hausa communities in Niger today, mostly by revealing some of the early episodes of conflicts that have resurfaced under different disguises. Of course, given the fact that this study has been based mostly on one tale by the storyteller Albarka Ciibaw, this conclusion and any other previous inferences are to be taken with caution. There is therefore a need for further investigations on a wider corpus of tales by the same storyteller and others from Niger.

\section{A Short Biography of Albarka Ciibaw}

Albarka Ciibaw, from whose repertoire the above tales have been taken, was born in Tahoua, the capital city of Adar in the north-eastern part of Niger republic. He never attended any Quranic or Western school and he was about 50 years old when he was invited to Niamey in 1971 for the recording of his tales at the Center for Linguistic and Historical Studies by Oral Tradition (Centre d'Etudes Linguistiques et Historiques par Tradition Orale/CELHTO), an OAU/AU institution. He claimed to have inherited his storytelling performance from his father and he was happy to pass down his art to his son, Mahamadu. Proud of his her- 
itage, Ciibaw advised people to take care of their cultural traditions because for him "There is harmony in a home where children observe tradition; where children walk in the steps of their parents even if the latter are non-Muslims" $(5)^{19}$. The storyteller's comments are a clear indication of cultural and religious tensions as the result of the political changes brought about by the Jihad. Ciibaw died some years ago. The following are the summaries of the two tales.

\section{Conflicts of Interest}

The author declares no conflicts of interest regarding the publication of this paper.

\section{References}

Ahmad, S. B. (2018). Construction of Identities in Hausa Tales. In Conference of the Nigerian Folklore Society on the Theme: Folklore and Folk Life in Nigeria: Prospects and challenges in 21st Century (pp. 1-14). Zaria: Ahamadu Bello University Press Limited.

Aminu, N. (2014). Argungun Folklore in the Archives of Frank Edgar. In A. Rasheed, \& S. A. Aliyu (Eds.), Folklore, Integration and National Development in Nigeria (pp. 18-23). Kano: Bayero University.

Baumgardt, U. (2011). Recontre des genres en littérature orale: De l'épique dans le conte. In Virginia Coulonet Xavier Garnier (Ed.), Les littératures africaines: textes et terrains (pp. 229-239). Paris: Karthala. https://doi.org/10.3917/kart.coul.2011.01.0229

Bello, G. (1976). Yabo, Zuga da Zambo a Wakokin Sarauta. Harsunan Nijeriya, 6, 21-34.

Besmer, F. E. (1973). Praise-Epithets and Song Texts for Some Important Bori Spirits in Kano. Harsunan Nijeriya, 3, 15-38.

Bichi, A. Y. (1979). Cultural Reflection in Hausa Folklore: An Introduction. Harsunan Nijeriya, 9, 99-111.

Bichi, A. Y. (1983/1985). The Meaning and Function of Hausa Riddles. Harsunan Nijeriya, $13,33-47$.

Bunza, A. M. (2009). Narambada. Lagos: Ibrash Islamic Publications Centre Ltd.

Dankuusu, I., \& Abuubakar, M. (1973/1979). Baakii abim magana: Hiirar Albarka Ciibaw (Volume I, pp. 29-40). Niamey: Centre d'études linguistique et historique par tradition orale (CELHTO).

Furniss, G. (1996). Poetry, Prose, and Popular Culture in Hausa. Washington DC: Smithsonian Institution Press.

Hamani, D. (2006). Etat et institutions politiques dans l'espace nigérien précolonial. In Histoire de lespace nigérien: Etat des connaissances (pp. 167-192). Niamey: Association des Historiens Nigériens/Editions Daouda.

Hiskett, M. (1989). Introduction. In Shaihu Umar (pp. 3-15). New York: Alhaji Sir Abubakar Tafawa Balewa.

Mahaman, A. (2006). Le jihad d'Usman dan Fodio. In Histoire de Pespace nigérien: Etat

19“kyaawan gida shi zan da magaadaa, uban mutun koo daa dooguwaa ya ajee shi dooki abuutay..." (Dankuusu and Mahaman 5).

The page numbering of the tales refers to the original versions with nonstandard transcription. But I sought the help of two Hausa linguists: Yawale, a Ph.D. student, changed the transcription into the standard one, available upon request. The other is Prof. Mahamane Laoualy Abdoulaye who read the entire article and made some suggestions. To both of them I express my deep gratitude.

NB: All translations are mine unless otherwise indicated. 
des connaissances (pp. 118-144). Niamey: Association des Historiens Nigériens/Editions Daouda.

Mahamane, A., \& Mahaman, A. (2006). Peuplement du Niger Centre. In Histoire de I espace nigérien: Etat des connaissances (pp. 45-64). Niamey: Association des Historiens Nigériens/Editions Daouda.

Mahamane, A. (2013). Le Panégyrique des Dignitaires Hausa. In Les Cahiers du CELHTO$U A$ (Volume I, pp. 129-153). Nouvelle Série, Cotonou: Les Editions du Flamboyant.

Maikorema, Z. (2006). Peuples et états du sud-est Nigérien. In Histoire de l'espace nigérien: Etat des connaissances (pp. 65-72). Niamey: Association des Historiens Nigériens/Editions Daouda.

Nwabara, S. N. (1963). The Fulani Conquest and the Rule of the Hausa Kingdom of Northern Nigeria (1804-1900). Journal de la société des Africanistes, 33, 231-242. https://doi.org/10.3406/jafr.1963.1370 https://www.persee.fr/doc/jafr_00379166_1963_num_33_2_1370

Oumarou, C. E. (2018). Critical Perspectives on Hausa Literature: A Comparative Criticism on the Oral-Written Interface. Beau Bassin: Noor Publishing.

Raulin, H. (1962). Un aspect historique des rapports de l'animisme et de l'Islam au Niger. Journal de lassociation des africanistes, 12, 249-274. https://doi.org/10.3406/jafr.1962.1359

Skinner, N. (1980). An anthology of Hausa Literature. Zaria: NNPC.

Skinner, N. (1977). Alhaji Mahmudu Kokf: Kano Malam (Translated and Edited by Neil Skinner). Zaria: Ahmadu Bello University Press.

Stephens, C. L. (1991). Marriage in the Hausa Tatsuniya Tradition: A Cultural and Cosmic Balance. In Hausa Women in the Twentieth Century (pp. 221-231). Madison, WI: The University of Wisconsin Press.

Stephens, C. L. (1981). The Relationship of Social Symbols and Narrative Metaphor: A Study of Fantasy and Disguise in the Hausa Tatsuniya of Niger (2 Vols.). Ph.D. Diss., Madison, WI: University of Wisconsin.

Yahaya, I. Y. (1972). The Style and Content of Hausa Tale. Harsunan Nijeriya, 2, 23-41. 